Pesq. Vet. Bras. 30(10):887-890, outubro 2010

\title{
Cortisol influence on testicular testosterone secretion in domestic cat: An in vitro study ${ }^{1}$
}

\author{
Gelson Genaro ${ }^{2}$ and Celso R. Franci²
}

\begin{abstract}
Genaro G. \& Franci C.R. 2010. Cortisol influence on testicular testosterone secretion in domestic cat: An in vitro study. Pesquisa Veterinária Brasileira 30(10):887890. Faculdade de Medicina de Ribeirão Preto, Universidade de São Paulo, Cx. Postal 390, Ribeirão Preto, SP 14001-970, Brazil. E-mail: ggenaro@ ffclrp.usp.br

The aim of the present experiment was to investigate the effect of corticosteroids (exogen) on in vitro testosterone secretion after stress by transportation (40 minutes). Feline testes (Felis silvestris catus) were incubated in the following media: TCM 199; TCM $199+$ hCG 10- $^{-}$ ${ }^{7} \mathrm{M}$; TCM 199 + hydrocortisone $10^{-7} \mathrm{M}$, or TCM $199+\mathrm{hCG}+$ hydrocortisone. The animals $(n=21)$ were allocated into three groups: $(S)$ that arrived at $3 \mathrm{~h}$ prior to surgery, $(A)$ that remained in the laboratory for $36 \mathrm{~h}$ before being submitted to surgical procedure, and $(C)$ that were also allowed to remain for 36 hours in the laboratory before the surgical procedure, but whose testes had been incubated with hydrocortisone prior to incubation in the referred media. The results showed that group $S$ secreted higher levels of testosterone, regardless of the culture media. It is noteworthy that the suppressing action of hydrocortisone sodium succinate led to a reduction in the testosterone concentration, despite the presence of hCG.
\end{abstract}

INDEX TERMS: Testosterone, domestic cat, cortisol, testis, stress, transport.

RESUMO.- [Ação do cortisol sobre a secreção de testosterona em testículos de gato doméstico: um estudo in vitro.] $\mathrm{O}$ objetivo deste trabalho foi investigar o efeito da hidrocortisona sobre a secreção de testosterona após cultivo in vitro dos testículos, em distintas situações de estresse (transporte) de gatos domésticos (Felis silvestris catus). Testículos foram incubados nos seguintes meios de cultura: TCM 199; TCM $199+$ hCG 10-7 M; TCM $199+$ hydrocortisona $10^{-7} \mathrm{M}$ e TCM $199+\mathrm{hCG}+$ hidrocortisona. Os animais $(n=21)$ foram alocados em 3 sub-grupos: (S) animal admitido 3 horas antes da orquiectomia, (A) animais orquiectomizados após 36 horas de permanência no biotério e $(C)$ animais que permaneceram por 36 horas no biotério antes da cirurgia e que tiveram seus testículos pré-incubados em hidrocortisona. Os resultados demonstraram que o grupo $S$ secretou maiores valores de testosterona em todas as condições estudadas. É válido mencionar que a supressão promovida pela hidrocortisona também promoveu redução na concentração de testosterona no meio TCM 199, a despeito da presença de hCG.

\footnotetext{
1 Received on August 19, 2009.

Accepted for publication on August 9, 2010.

2 Faculdade de Medicina de Ribeirão Preto, Universidade de São Paulo (FMRP-USP), Cx. Postal 390, Ribeirão Preto, SP 14001-970, Brazil. " Corresponding author: ggenaro@ffclrp.usp.br
}

TERMOS DE INDEXAÇÃO: Testosterona, gato doméstico, cortisol, testículo, estresse, transporte.

\section{INTRODUCTION}

Despite evidences that stress exerts influence on reproductive functions, the interactions between the hypothalamus-pituitary-adrenal (HPA) and gonadal (HPG) axes remain unclear (Moberg 1991, Baldwin et al. 1996, Fenske 1997, Ferasin 2001, Genaro et al. 2003, Lacerda Neto et al. 2004, Bridges et al. 2005). There are indications of both inhibiting (Bambino \& Hsueh 1981, Welsh et al. 1982, Genaro et al. 2003) and stimulating (Faulborn et al. 1979, Welsh \& Johnson 1981) effects of the HPA axis on HPG. The hypothalamus secretes the Gonadotrophin Releasing Hormone $(\mathrm{GnRH})$, and the pituitary, which secretes the Luteinizing Hormone (LH) and the Follicle Stimulating Hormone (FSH), as well as testis (a gland that secretes testosterone $(T)$ can be both the target of hormones belonging to the HPA axis (Willard et al. 1995).

These hormonal interactions depend on various factors such as species, sex, age, social class, animal housing and others (Welsh \& Johnson 1981, Brown et al. 1988, Tasker et al. 1999, Barber 2004, Genaro et al. 2004, 2007). Overall, hormone secretion by the HPA axis is inversely proportional to the activity of the HPG axis (Willemse et al. 1993). Therefore, the suppressing effect of stress on 
reproduction should be mainly due to the reduced secretion of sexual hormones (to a review: Moberg, 1991).

The majority of studies on the domestic cat (Felis silvestris catus) focus on female endocrinology (Kirkpatrick 1985, Silva et al. 2009). Still, if species-specificities are considered, studies using domestic cats are a possible effective model for the investigation of various aspects of the reproductive function of the Felidae family, with many endangered species (Genaro et al. 2007).

The present study aimed to evaluate the effect of cortisol on testicular testosterone secretion following acute stress by animal transportation and/or lack of environmental adaptation through an in vitro study in domestic cats.

\section{MATERIALS AND METHODS}

Twenty-one male cats (2-3 years of age, body weight $4-5 \mathrm{~kg}$ ), kindly provided by non-governmental organizations were allocated equally into three experimental groups: $A(n=7), C$ $(n=7)$, and $S(=7)$, as described in Table 1 (July-December).

After 40 minutes of transportation, the animals were housed indoors in individual $1-\mathrm{m}^{3}$ stainless-steel cages with commercial dry food and water provided ad libitum.

The three experimental groups underwent two distinct presurgical treatments that differed in the number of hours allowed for the adaptation to the laboratory housing. Animals from Groups $\mathrm{A}$ and $\mathrm{C}$ arrived 36 hours prior to the surgical procedure and were kept at the laboratory housing of the Physiology Department (FMRP-USP) in the conditions described in the paragraph above Group $S$ arrived at the laboratory 3 hours before the surgery. All animals were maintained under controlled temperature $\left(23 \pm 2^{\circ} \mathrm{C}\right)$ and fasted for $12 \mathrm{~h}$ before surgery irrespective of the adaptation period length.

Animals were anesthetized with a combination of ketamine $\mathrm{HCl}(20 \mathrm{mg} / \mathrm{kg}$, im, Francotar, Virbac-Brasil) and xylazine (1mg/ $\mathrm{kg}$, im, Coopazine, Coopers-Brasil). An attempt was made to minimize animal disturbance before the injections. Immediately before the surgical procedure and after anesthesia, $1.0 \mathrm{ml}$ of venous blood was collected from the right forelimb (Cephalic vein) for determination of plasma testosterone.

Following orchiectomy, right and left testis were denuded and divided into four fragments. These fragments (one from each testis) were pre-incubated pair wisely for 60 minutes in TCM 199 culture medium (Gibco-USA, containing $0.1 \mathrm{mg} / \mathrm{ml}$ of bovine serum albumin, fraction $\mathrm{V}$, Hepes $15 \mathrm{mM}$ in $\mathrm{pH} 7.4$ ). The testes from animals belonging to Group $C$ (only) received hydrocortisone $\left(10^{-7} \mathrm{M}\right)$ during the pre-incubation period. After pre-incubation, each fragment (To Groups: A, C and S) was submitted to two periods of sixty-minute (first and second hour) of incubation in one of the following conditions:

1) TCM 199 culture medium;

2) TCM 199 culture medium containing human Chorionic Gonadotrophin 10-7 M (hCG-Pregnyl 1500 UI, Akzo Nobel Ltda, Organon, Brazil);

3) TCM 199 culture medium containing hydrocortisone 10${ }^{7} \mathrm{M}$ (Hydrocortisone Sodium Succinate, União Química Farmacêutica Nacional S/A, Brazil);

4) TCM 199 culture medium containing hydrocortisone $10^{-}$ ${ }^{7} \mathrm{M}$ and $\mathrm{hCG} 10^{-7} \mathrm{M}$.

Both the pre-incubation of $C$ group and the incubation of $A$, $\mathrm{C}$ and $\mathrm{S}$ were carried out under continuous stirring (80 cycles/ minute) at a temperature of $38.8^{\circ} \mathrm{C}$ (without $\mathrm{CO} 2$ control). At the end of each sixty-minute period, the total medium volume (1 $\mathrm{ml}$ ) was collected and substituted for an equal volume of the same medium containing the same initial compounds. The medium obtained after the pre-incubation period was discarded. The medium collected after the incubations was frozen $\left(-20^{\circ} \mathrm{C}\right)$ for further evaluation of testosterone by radioimmunoassay.

Testosterone was determined by radioimmunoassay using ${ }^{3} \mathrm{H}$-testosterone from NEN Life Science Products (Boston, USA). The specific antibody was kindly provided by Dr. José AntunesRodrigues (USP-Ribeirão Preto, Brazil). All samples were analyzed in a single assay. The lower detection limit was $0.16 \mathrm{ng} /$ $\mathrm{ml}$. The intra-assay variation coefficient was $5.4 \%$.

The data (mean \pm SEM) for each group (according to experimental groups or medium) were analyzed by one-way ANOVA followed by the Tukey test when applicable, using the Prism 2.01 program, with the level of significance set at $\left(^{*}\right) p<0.05$.

\section{RESULTS AND DISCUSSION}

There were no significant statistical differences between the plasma testosterone concentration values obtained by animals belonging to Group S (which had arrived at the laboratory 3 hours before surgery) and those of animals belonging to groups $\mathrm{A}$ and $\mathrm{C}$ (which had been allowed to adapt for 36 hours). These values were $0.21 \pm 0.03 \mathrm{ng} / \mathrm{ml}$ and $0.20 \pm 0.03 \mathrm{ng} / \mathrm{ml}$, respectively.

The values of secreted testosterone (ng) per gram of testis obtained with the different groups and culture conditions are depicted in Figure 1. Testosterone secretion was significantly higher $(p<0.05)$ in group $S$ compared with groups $A$ and C, in both the control conditions (TCM 199, only) and the three different culture conditions. The four different treatments (TCM 199 culture medium, hCG, Cortisol and $h C G+C o r t i s o l)$ led to the same secretion profile $(S>A \approx C)$.

Table 1. Experimental groups

\begin{tabular}{|c|c|c|c|}
\hline $\begin{array}{l}\text { Group } \\
\text { Treatment }\end{array}$ & Group A & Group C & Group S \\
\hline $\begin{array}{l}\text { Adaptation period } \\
\text { (Pre-surgical) } \\
\text { In vivo }\end{array}$ & $36 \mathrm{~h}$ & $36 \mathrm{~h}$ & $3 \mathrm{~h}$ \\
\hline $\begin{array}{c}\text { Pre -Incubation } \\
\text { In vitro }\end{array}$ & TCM 199 culture medium & TCM 199+hydrocortisone & TCM 199 culture medium \\
\hline $\begin{array}{l}\text { Incubation } \\
\text { In vitro }\end{array}$ & $\begin{array}{c}\text { TCM199(only) } \\
\text { TCM199+hCG } \\
\text { TCM199+Hydrocortisone } \\
\text { CM199+hCG+Hydrocortisone }\end{array}$ & $\begin{array}{c}\text { TCM199(only) } \\
\text { TCM199+hCG } \\
\text { TCM199+Hydrocortisone } \\
\text { TCM199+hCG + Hydrocortisone }\end{array}$ & $\begin{array}{c}\text { TCM199 (only) } \\
\text { TCM199+hCG } \\
\text { TCM199+Hydrocortisone } \\
\text { TCM199+hCG+Hydrocortisone }\end{array}$ \\
\hline
\end{tabular}

Pesq. Vet. Bras. 30(10):887-890, outubro 2010 
(199 Medium)

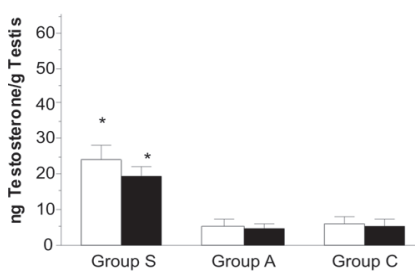

(Cortisol)

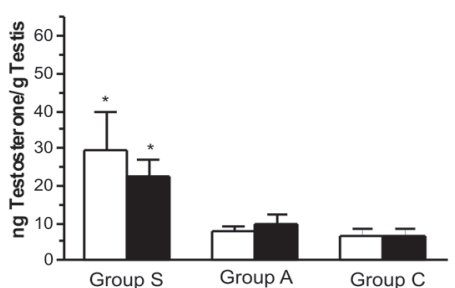

(hCG)
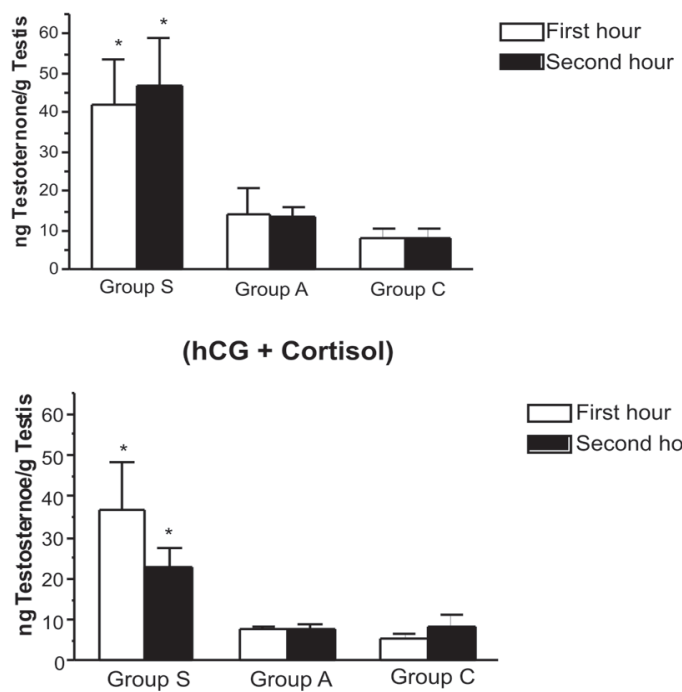

Fig.1. Testosterone secreted by testis fragments incubated in vitro (adult cats) in the following experimental conditions ( $n: 7$, to each group): Group S: cats allowed to habituate for 3 hours; Group A: cats habituated for 36 hours; Group C: cats habituated for 36 hours, whose testis fragments were pre-incubated with Hydrocortisone Sodium Succinate for 15 minutes prior to incubation. Incubation: the testis fragments were kept in the three above-mentioned conditions (Groups S, A and C) and incubated in vitro for 2 hours in four different experimental conditions: 199 culture medium (control), or 199 culture medium containing either hCG $10^{-7} \mathrm{M}$, Hydrocortisone $10^{-7} \mathrm{M}$, or hCG $10^{-7} \mathrm{M}+$ Hydrocortisone $10^{-7} \mathrm{M}$. $\mathrm{P}<0.05$ for significant differences between groups, within each treatment (199 medium, hCG, cortisol and hCG+cortisol). $\mathrm{P}<0.05$ for significant differences between groups A and S, when 199 medium and hCG were compared. (*: differences between A, C and S groups)

Testosterone secretion increased significantly $(p<0.05)$ comparing the first and second incubation periods when hCG was added to the medium of the experimental groups $A$ and $S$. This increment did not take place in group C, where the testis had been pre-incubated with hydrocortisone. In the latter case, pre-incubation with cortisol suppressed the stimulating action of hCG.

This study demonstrated that Leydig cells from animals submitted to acute stress (transportation carried out only $3 \mathrm{~h}$ prior to the surgical procedure, Group S) secrete higher testosterone levels (in vitro) than testis cells from animals allowed to habituate for $36 \mathrm{~h}$ following transportation (groups A and C) Group S presented higher testosterone levels than the other two groups, irrespective of the treatment (hCG, hydrocortisone, or hCG + hydrocortisone). The acute stress was effective in altering the gland control, leading to increased testosterone release from the testis (in vitro) to the incubation medium.

Adrenal activity exerts suppressing effects on the testicular function. Paradoxically, however, it can also have a stimulating effect over the reproductive function (Brown et al. 1988). Stimulation of the reproductive axis by adrenal hormones under acute stress suggests that the response may depend on the duration and intensity of the stimulus (Armario et al. 1987). Glucocorticoids may facilitate gonadotrophin secretion via interaction with gonadal steroids (Kamel \& Kubajak 1987). Additionally, Corticotropin Release Hormone $(\mathrm{CRH})$ administration in the third ventricle stimulates LH secretion in a dose-dependent manner (Naylor et al. 1990). On the other hand, Fenske (1997) performed in vitro studies showing that the mechanism of testicular function inhibition by cortisol does not depend on plasma LH concentrations since cortisol would be capable of acting directly on Leydig cells. This would probably occurs through inhibition of the enzymes 17 a-hydroxylase and/or C17,20 -lyase, thus indicating a specific action (local) on the testis.

Wildt et al. (1988) showed that the effect of increased adrenal activity on testosterone (in vivo) is insignificant in cheetahs (Acynonyx jubatus) and pumas (Puma concolor), ambiguous in tigers (Panthera tigris), and suppressing in leopards ( $P$. pardus). Therefore, cortisol is able to exert a species-specific influence on the activity of reproductive hormones in species belonging to the Felidae family. So a better understanding of these interactions should help control the reproductive function of these species, some of which are classified as endangered.

Acute stress (Willemse et al. 1993, Fenske 1997, Lacerda Neto et al. 2004) such as the one undergone by group $\mathrm{S}$, seems to sensitize the Leydig cells for an exacerbated response in the control condition (TCM 199 medium). Because pre-icubation (group C) and incubation with cortisol (groups A and C) does not alter testosterone secretion, it is probable that Leydig cell sensibilization under acute stress is not mediated by cortisol, but by some other mediator released during a stressful condition. In a recent in vivo study (Genaro et al. 2007), we have shown that cortisol plasma concentrations were higher in animals submitted to stress by transportation, as in the case of group $S$, than 
in groups allowed to habituate to the environment, like groups $\mathrm{A}$ and $\mathrm{C}$.

The fact that pre-incubation and/or incubation with hydrocortisone prevents the stimulating action of hCG over testosterone secretion in groups $\mathrm{A}$ and $\mathrm{C}$, but not in group $S$ indicates that hydrocortisone acts as an inhibitor of testosterone release stimulated by hCG, but it does not inhibit testosterone secretion due to acute stress. Therefore, such effect of hydrocortisone is not able to prevent Leydig cell sensitization by acute stress, which reinforces the idea that this sensitization is mediated by a factor other than hydrocortisone.

Studies involving these hormonal axes are still mandatory to increase our knowledge on the reproductive function of the Felidae family, which should enable one to use this information for a better handling of reproduction and captivity, especially in the case of the endangered species. The domestic cat can thus be employed as an important model in these studies.

\section{CONCLUSIONS}

The results showed that fragment of testis from cats under stress secreted higher levels of testosterone in vitro than those from animals without stress.

The three groups presented variations in testosterone concentrations in response to hCG; however, secretion by group $S$ was significantly higher than those by groups $A$ and $\mathrm{C}$.

With respect to group $S$, it is noteworthy that the suppressing action of hydrocortisone led to a reduction in the testosterone in pure TCM 199 when cortisol was included in the medium, despite the presence hCG.

Acknowledgements.- This research was supported by grants from Fundação de Amparo à Pesquisa do Estado de São Paulo (FAPESP, Proc. no. 99/07785-4). Thanks are also given to Ms. Sônia A. Zanon for excellent assistance during the radioimmunoassay. We are also extremely grateful to the Non Governmental Organizations from Ribeirão Preto, SP: A.V.A. (Associação Vida Animal de Ribeirão Preto, SP), GRU.A.BI (Grupo Amigo dos Bichos de Ribeirão Preto, SP) and "The $B$ Shelter" from the owner José Artur Berti for kindly providing the animals. Thanks are extended to the present Editor (Pesquisa Veterinária Brasileira - Morfofisiologia) and the reviewers who provided very helpful comments on the manuscript.

\section{REFERENCES}

Armario A., Restrepo C., Hidalgo J. \& Lopez-Calderon A. 1987. Differences in $\mathrm{Prl}$ and $\mathrm{LH}$ to acute stress between peripuberal and adult male rats. J. Endocrinol. 112:9-13.

Baldwin C.J., Peter A.T. \& Bosu W.T.K. 1996. Adrenocortical function in the domestic cat during treatment with levonorgestrel. Res. Vet. Sci. 60:205-208.

Bambino T.H. \& Hsueh A.J.W. 1981. Direct inhibitory effect of glucocorticoids upon testicular luteinizing hormone receptor and steroidogenesis in vivo and in vitro. Endocrinol. 108:2142-2148.

Barber P.J. 2004. Disorders of the parathyroid glands. J. Feline Med. Surg. 6:259-269.

Bridges P.J., Brusie M.A. \& Fortune J.E. 2005. Elevated temperature (heat stress) in vitro reduces androstenedione and estradiol and increases progesterone secretion by follicular cells from bovine dominant follicles. Domestic Anim. Endocrinol. 29:508-522.

Brown J.L., Goodrowe K.L., Simmons L.G., Armstrong D.L. \& Wildt D.E. 1988. Evaluation of the pituitary-gonadal response to $\mathrm{GnRH}$, and adrenal status, in the leopard (Panthera pardus japonensis) and tiger (Panthera tigris). J. Reprod. Fertil. 82:227-236.

Faulborn K.W., Fenske M., Pitzel L. \& König A. 1979. Effects of an intravenous injection of tetracosactid on plasma corticosteroid and testosterone levels in unstressed male rabbits. Acta Endocrinol. 91:511-518.

Fenske M. 1997. Role of cortisol in the ACTH-induced suppression of testicular steroidogenesis in guinea pigs. J. Endocrinol. 154:407414.

Ferasin L. 2001. latrogenic hyperadrenocorticism in a cat following a short therapeutic course of methylprednisolone acetate. J. Feline Med. Surg. 3:87-93.

Genaro G., Lacerda Neto J.C. \& Rosa e Silva A.A.M. 2003. LH response (in vivo and in vitro) to an LHRH agonist administered to domestic male cats. Arch. Phys. Biochem. 111:254-258.

Genaro G., Schmidek W.R. \& Franci C.R. 2004. Social condition affects hormone secretion and exploratory behavior in rats. Braz. J. Med. Biol. Res. 37:833-840.

Genaro G., Moraes W., Silva J.C.R., Adania C.H. \& Franci C.R. 2007. Plasma hormones in neotropical and domestic cats undergoing routine manipulations. Res. Vet. Sci. 82:263-270.

Kamel F. \& Kubajak C.L. 1987. Modulation of gonadotropin secretion by corticosterone: interaction with gonadal steroids and mechanism of action. Endocrinol. 121:561-568.

Kirkpatrick J.F. 1985. Seasonal testosterone levels, testosterone clearance, and testicular weights in male domestic cats. Can. J. Zool. 63:1285-1287.

Lacerda Neto J.C., Barbosa J.C., Lunardi L.O., Rosa e Silva A.A.M. \& Genaro G. 2004. Effects of surgical stress on the secretion of luteinizing hormone, testosterone and cortisol in the domestic cat (Felis catus). Ciênc. Anim. Bras. 5:211-214.

Moberg G.P. 1991. How behavioral stress disrupts the endocrine control of reproduction in domestic animals. J. Dairy Sci. 74:304-311.

Naylor A.M., Poter D.W.F. \& Lincoln D.W. 1990. Central administration of CRF in the sheep: Effects on secretion of gonadotropin, prolactin and cortisol. J. Endocrinol. 124:117-125.

Silva C.A.O., Perri S.H.V., Koivisto M.B., Silva A.M., Carvalho R.G. \& Monteiro C.M.R. 2009. Aspectos histológicos e morfométricos dos testículos de gatos domésticos (Felis catus). Pesq. Vet. Bras. 29(4):312-316.

Tasker S., Mackay A.D. \& Sparkes A.H.S. 1999. A case of feline primary hypoadrenocorticism. J. Feline Med. Surg. 1:257-260.

Welsh T.H., Bambino T.H. \& Hsueh A.J.W. 1982. Mechanism of glucocorticoid-induced suppression of testicular androgen biosynthesis in vitro. Biol. Reprod. 27:1138-1146.

Welsh T.H. \& Johnson B.H. 1981. Stress-induced alterations in secretion of corticosteroids, progesterone, luteinizing hormone, and testosterone in bulls. Endocrinol. 109:185-190.

Wildt D.E., Phillips L.G., Simmons L.G., Chakraborty P.K., Brown J.L., Howard J.G., Terae A. \& Bush M. 1988. A comparative analysis of ejaculate and hormonal characteristics of the captive male cheetah, tiger, leopard and puma. Biol. Reprod. 38:245-255.

Willard S.T., Carroll J.A., Randel R.D., Harms P.G. \& Welsh Jr T.H. 1995. Regulation of adrenocorticotropin in vitro by anterior pituitary corticotrophs from fallow deer (Dama dama). Domestic Anim. Endocrinol. 12:283-292.

Willemse T., Margreet W.V., Mol J.A. \& Rijnberk A. 1993. Changes in plasma cortisol, corticotropin, and a-melanocyte-stimulating hormone concentrations in cats before and after physical restraint and intradermal testing. Am. J. Vet. Res. 54:69-72. 